Återblick på den senaste förändringen af den tyska banklagen

Author(s): G. Cassel

Source: Ekonomisk Tidskrift, Årg. 1 (1899), pp. 365-382

Published by: Wiley on behalf of The Scandinavian Journal of Economics

Stable URL: http://www.jstor.org/stable/3436888

Accessed: 27-06-2016 09:44 UTC

Your use of the JSTOR archive indicates your acceptance of the Terms \& Conditions of Use, available at

http://about.jstor.org/terms

JSTOR is a not-for-profit service that helps scholars, researchers, and students discover, use, and build upon a wide range of content in a trusted digital archive. We use information technology and tools to increase productivity and facilitate new forms of scholarship. For more information about JSTOR, please contact support@jstor.org.

Wiley, The Scandinavian Journal of Economics are collaborating with JSTOR to digitize, preserve and extend access to Ekonomisk Tidskrift 


\title{
Återblick på den senaste förändringen af den tyska banklagen.
}

\author{
Af G. Cassel.
}

Den tyska banklagen af den I4 mars I 875 hade senast förnyats I 889 och därmed också de sedelutgifvande bankernas privilegium förlängts på ıo år. I 899 års riksdag skulle således ha att besluta öfver eventuella förändringar $\mathrm{i}$ grunderna för det tyska bankväsendet, och i medvetande härom hade oppositionen redan långt förut satt $\mathrm{i}$ gång en häftig agitation. Denna opposition utgick väsentligen från agrariskt håll. Tendensen att i ekonomiska svårigheter uppsöka källan till det onda i ett enda yttre moment, helst ett sådant, där man kan tänka sig, att statens makt skall kunna skaffa hjälp, den tendensen tycks vara mycket allmänt utbredd och är ju i grunden ganska förklarlig. Den enskilde hushållaren, som ej förmår öfverskåda den mängd olika faktorer, som bestämmer det ekonomiska läget, och som under alla omständigheter är obenägen att söka felet hos sig själf, är i det politiska lifvet så godt som förutbestämd för denna riktning. Tysklands agrarer ha nu också sedan 20 år tillbaka fått vänja sig vid att $\mathrm{i}$ alla trångmål lita på statens hjälp. Men trots allt hvad de sålunda lyckats vinna genom politiska medel, var agrarernas ställning, som bekant, ännu alltjämt otillfredsställande.

Då kom med år I895 det stora ekonomiska uppsvinget, som började inom järnhandteringen och utbredde sig till större delen af Tysklands industri och handel. Denna rörelse ställde framför allt enorma anspråk på kapitalbildningen. Den naturliga 
följden häraf var en räntestegring, som fann sitt första uttryck i riksbankens diskontosatser. Dessa utgjorde i årsgenomsnitt:

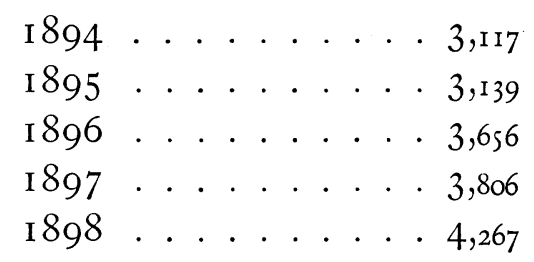

Denna stegring måste till sist inverka på de fast förräntade pappernas kurs. Dessa papper ha också särskildt under år I 898 förlorat högst betydligt. Så t. ex. noterades 3-procentiga ReichsAnleihen ännu i början af I 897 till $99 \%$, men hade den 25 oktober I 898 fallit till 92,50 .

Under sådana förhållanden var det klart, att nya hypotekslån ej längre kunde komma att erhållas till de gamla billiga betingelserna: till landtbrukets alla öfriga bekymmer kommo stegrade kostnader för anskaffandet af kapital.

Den gamla agrarisk-bimetallistiska agitationen för uppnåendet af högre varupris genom en direkt försämring af landets valuta hade längesedan kommit till medvetande om sin fullständiga utsiktslöshet och kastade sig nu i stället med så mycket större ifver öfver räntefoten. Stegringen af densamma fick ej längre gälla som ett naturligt resultat af ett i sig själft glädjande ekonomiskt uppsving; nej det var börsen, som genom sina spekulationer drifvit upp räntefoten. Till en viss grad torde väl detta vara sant: den tyska marknaden har under de senare åren belastats med en betydlig mängd utländska lån, af hvilka en icke ringa del tillhör de så kallade spekulationspappernas område: om allt det tyska kapital, som nu ligger i mexikanska, argentinska eller kinesiska lån, stannat inom landet, skulle sannolikt den nuvarande penningställningen varit något lättare. Men å andra sidan måste man väl antaga, att de tyska kapitalisterna placera sina pengar, där de ha de bästa utsikterna, och för ett land i sin helhet är det alltid en fördel att besitta en del goda utländska papper: de tjäna, som Siemens ${ }^{1}$ uttryckte sig i riksdagen, still resårkuddar vid utjämningen af den internationella betalningsbalansen». Det agrariska förslaget att förbjuda införandet af utländska lån

\footnotetext{
${ }^{1}$ Direktören för »die Deutsche Bank».
} 
på de tyska börserna, så snart räntefoten öfverstigit $4 \%$, måste naturligtvis betecknas som ett otillbörligt förmynderskap.

Denna sträfvan att genom yttre påtryckningar nedbringa räntefoten trodde sig nu i bankpolitiken ha funnit ett utmärkt medel för sina syften. Och så kom det sig, att man till sist gjorde en felaktig banklagstiftning, kanske också en felaktig ledning af banken ansvariga för räntefotens stegring. I dessa förutsättningar finna agrarernas ändringsförslag en viss enhetlig förklaring.

Som bundsförvandter till agrarerna uppträdde antisemiterna, hvilka väl väsentligen leddes af sitt hat till »la haute finance»; härtill kom den inom olika partier företrädda bimetallistiska riktningen, som gaf oppositionens olika förslag sin egendomliga färg, om den också undvek att öppet plädera för sina egentliga principer.

Gent emot denna agrarisk-bimetallistisk-antisemitiska opposition stod den öfriga riksdagen tämligen kompakt på den gamla banklagens ståndpunkt. En särskild ställning intog likväl den sydtyska partikularismen, som strängt höll på privatbankernas privilegier gent emot vissa ändringsförslag från regeringens sida, hvilka vi längre fram få tillfälle att lära känna. Regeringen å sin sida var redan på förhand fast besluten att ej uppge en tum af själfva grunderna för det tyska bankväsendet, men om möjligt söka genomföra några mindre förbättringar.

Under sådana förhållanden voro naturligtvis agrarernas längstgående fordringar fullkomligt utsiktslösa; i öfrigt afgjordes de viktigare frågorna genom kompromisser. Vill man förstå banklagen i dess nya affattning, är det nödvändigt att taga kännedom om behandlingen af dessa frågor, och jag har därför trott mig kunna påräkna den svenska publikens intresse för en skildring af denna behandling, i synnerhet som den berör ekonomiska frågor af ett lika djupgående som universellt intresse.

\section{Riksbank eller privatbank.}

Sannolikt ha agrarerna $i$ ett förstatligande af riksbanken sett ett viktigt medel för förverkligandet af sin bankpolitik. Emellertid läto de ej denna synpunkt komma fram i debatten; här ställde de den finansiella sidan fullkomligt i förgrunden: riks- 
banken hade under åren $\mathrm{I} 89 \mathrm{I}-\mathrm{I} 897 \mathrm{i}$ medeltal pr år till sina aktieägare fördelat omkr. 8,400,000 mark, hvilket utgör $7 \%$ af det till I 20 millioner mark uppgående aktiekapitalet; om riket $\mathrm{i}$ stället till en räntefot af $3 \frac{1}{2} \%$ upplånat detta grundkapital och drifvit banken för egen räkning, skulle en besparing af omkr. 4 mill. mark årligen tillfallit rikskassan. Denna räkning varierades under debatten i många former; tar man hänsyn till, att banken besitter en reservfond på 30 mill. mark, hvilken till hälften tillhör aktieägarne, så blir den beräknade vinsten af ett förstatligande visserligen något mindre; men en årlig vinst af 3 à $3^{1 / 2}$ millioner mark är nu i alla fall en faktor, som man icke precis kan negligera, och agrarerna voro därför $i$ en ganska stark ställning, då de gent emot regeringspartiet häfdade sakens obestridliga finansiella betydelse.

Regeringen ställde sig emellertid absolut afvisande gent emot hvarje tanke på ett förstatligande af banken. För oss svenskar, som äro i det tämligen unika läget att äga en statsbank, kan det vara af intresse att taga kännedom om de skäl, som i denna fråga voro bestämmande för tyska regeringen. Den väsentligaste egendomligheten i den tyska riksbankens författning är, att banken, ehuru stödd på ett privat aktiekapital, dirigeras af ett af kejserliga ämbetsmän sammansatt bankdirektorium. Aktieägarnes representation, det s. k. centralutskottet, har vid sidan af detta direktorium $\mathrm{i}$ hufvudsak endast en rådgifvande ställning. Men just vid detta rådgifvande utskott lägga det tyska banksystemets anhängare den allra största vikt: detta utskott tänkes som ett förmedlande band mellan direktionen och affärsvärlden, ett band, för hvilket det skulle vara svårt att finna en ersättning, om banken fullständigt öfverginge i statens ägo. Men än mer: detta centralutskott har en viktig vetorätt ${ }^{1}$, som sätter det i stånd att motsätta sig alla extra anspråk från statens sida och sålunda värna banken från ett otillbörligt fiskaliskt inflytande. Denna vetorätt är i själfva verket att betrakta som en hörnsten $\mathrm{i}$ den tyska bankförfattningen. Under ett statsbanksystem skulle man aldrig - detta uttalades af regeringens ombud statssekreteraren von Posadowsky — „ullständigt kunna skilja riksfinan sförvaltningens

1 Banklagens $\int 35$; jfr $\ 32$ afd. 2 Litt. d. 
synpunkter från riksbankförvaltningens». Von Posadowsky vädjade också till uttalanden vid den senaste reformen af den franska banken: "la banque d'Etat c'est la politique mêlée aux affaires", ett uttalande som han öfversatte: »eine Staatsbank wird sich gewissen politischen Einflüssen auf die Länge gar nicht entziehen können.» Ja, riksbankens president anförde uttalanden från samma franska debatt, sådana som den dåvarande referenten Lebon's: »att votera en statsbank är att ge regeringen rätt att ge ut papperspengar.»

Den dominerande synpunkten i striden öfver principfrågan statsbank eller privatbank var likväl en annan, nämligen bankens folksrättsliga ställning i händelse af krig. Banklagens anhängare hänvisade till, att banken, så länge den förblir privat egendom, är skyddad för konfiskering vid en eventuell fiendtlig invasion. Man påpekade, att Tyskland 1870 respekterat franska bankens karakter af privategendom, och att t. o. m. Paris' kommunarder gjort detsamma. Oppositionen invände, att det icke var så säkert, att Tysklands fiender skulle komma att iakttaga samma måttfullhet. Det är naturligtvis omöjligt att med bestämdhet afgöra en sådan fråga; men det faktum, att regeringens företrädare upprepade gånger hänvisade till privatbanksystemets väsentliga fördelar i krigsfall, synes mig väga synnerligen tungt.

Det är för öfrigt icke endast den direkta faran för en konfiskering, som vid ett krigsfall kommer i betraktande. Redan vid fiendens annalkande måste en statsbanks direktörer som statsämbetsmän draga sig undan med bankens kassor, under det en privatbank lugnt kan fortsätta sin rörelse. Redan vid krigsfara skulle deponenterna utan tvifvel föredraga att placera sina pengar på ett säkrare ställe än $\mathrm{i}$ en statsbank. För staten är det för öfrigt alldeles icke behagligt att ikläda sig ansvaret för depositionerna, som i tyska riksbanken pläga uppgå till omkring en half milliard. Skulle dessa i krig eller vid uppror konfiskeras, skulle staten, $\mathrm{i}$ fall den vore ägare af banken, knappast kunna undandraga sig ersättningsskyldighet. Slutligen kan en privatbank på helt annat sätt stödja landets kredit under ett krig: staten kan då ha ganska dålig kredit, men banken likväl bibehålla sin och därigenom blifva till ett ovärderligt stöd. Detta visade sig i fransk-tyska 
kriget: Thiers har bekräftat det med orden: "banken har räddat landet, därigenom att den icke är en statsbank.»

I medvetande om den fullständiga utsiktslösheten för ett förstatligande af riksbanken hade oppositionen nöjt sig med att föreslå, att riket skulle öfvertaga de nya aktierna vid den tillämnade kapitalförhöjningen. Af banklagens anhängare betraktades detta förslag med rätta som ett försök att på omvägar komma fram till en statsbank, och förslaget blef i enlighet härmed afvisadt.

\section{Aktieägarnes vinstandel.}

Oppositionen, som öfverhufvud var synnerligen fiendtligt stämd mot aktieägarne, men naturligtvis också leddes af en fullt berättigad omsorg om rikets finanser, sträfvade att inskränka aktieägarnes vinst $\mathrm{i}$ betydlig högre grad än regeringen föreslagit. För att äga en motvikt mot allt vidare tal om den finansiella fördelen af en statsbank, måste banklagens anhängare i fråga om vinstfördelningen göra eftergifter. Härtill kom att socialisterna, som i frågan om bankens förstatligande öfvergifvit sina allmänna principer och ställt sig på privatbanksystemets sida, nu ville visa, att de alls icke tänkte på att ge "storkapitalisterna» några vänskapsgåfvor. Sedan reservfondsdotationerna i89 I hade afslutats, hade bankens aktieägare enligt villkoren i 1889 års privilegieförnyelse erhållit en ordinarie dividend af $3 \% \frac{1}{\%}$. Öfverskottet delades lika mellan rikskassan och aktieägarne, till dess de senare erhållit tillsammans $6 \%$, hvarefter aktieägarne fingo $1 / 4$, riket $3 / 4$ af hvad som ytterligare kunde återstå. Regeringen föreslog nu att uppbringa reservfonden från 30 till 60 millioner mark; för detta ändamål skulle, sedan aktieägarne erhållit sin ordinarie utdelning af $3 \% \%, 20 \%$ af den återstående vinsten afsättes till reservfonden; af öfverskottet skulle aktieägarne få hälften så länge deras totaldividend ej öfversteg $5 \%$, sedan $1 / 4$.

Oppositionen föreslog en absolut begränsning af dividenderna till $6 \%$, socialisterna t. o. m. till $5 \%$. Från motsidan betecknades hvarje absolut begränsning som oförenlig med aktiernas natur: dessa skulle genom oppositionens förslag väsentligen erhålla karakteren af obligationer, och banken i sin ordning i viss mån naturen af en statsbank. Förslagen förkastades. 
Enligt den nu fastställda banklagen går, sedan aktieägarne först fått sina $3^{1 / 2} \%$, och reservfonden doterats som sagts, $1 / 4$ af öfverskottet till aktieägarne, hvarefter riket får resten - alltså en ganska väsentlig försämring af aktieägarnes ställning.

\section{Aktiekapitalets förhöjning.}

Agrarerna hade fått för sig, att den höga räntefoten $\mathrm{i}$ väsentlig mån var att hänföra till riksbankens, enligt deras mening, svaga ställning. De riktade därför $\mathrm{i}$ främsta rummet sin sträfvan på att stärka bankens guldförråd. Ett första medel härtill var i deras ögon en betydlig förhöjning af bankens eget kapital.

Gent emot denna egendomliga uppfattning gjorde regeringen gällande, att en sedelbank $\mathrm{i}$ sina depositioner och $\mathrm{i}$ sina sedlar har sitt egentliga rörelsekapital, vid sidan af hvilket det egna kapitalet hufvudsakligen har karakteren af en garantifond. Riksbankens kapital uppgick som nämndt förut till I 20 mill. mark, hvartill kom reservfonden, 30 mill. mark, tillsammans alltså I5O mill. mark. Äfven en relativt stor ökning af detta kapital skulle uppenbarligen, betraktad som en ökning af rörelsekapitalet, vara obetydlig för en bank, som den 3 I sistlidne december hade en obetäckt sedelutgifning på öfver 576 mill. mark och en total på öfver I,357 mill. mark. Och för öfrigt, hvad skulle riksbanken under mellantider af riklig penningtillgång göra med sina kapital? Man måste tänka på hur oerhördt växlande de kraf äro, som ställas på ett sådant institut: den 23 februari 1898 hade riksbanken en till öfver $2 S$ mill. mark uppgående öfvertäckning af sina utelöpande sedlar. Dả banken måste akta sig för att genom en alltför låg diskont påtruga marknaden sina sedlar, skulle den alltså åtminstone tiduvis vara tvungen att anlägga sitt kapital i räntebärande papper. Men detta är just hvad banken hittills principiellt undvikit, ledd af den utan tvifvel mycket sunda uppfattningen, att en stor centralbank framför allt måste hålla sina medel likvida.

A andra sidan hade banken under de senare åren fastlagt rätt betydande summor $\mathrm{i}$ sina fastigheter ${ }^{1}$ - dessa summor

${ }^{1}$ Det fanns vid slutet af 1898 utom hufvudkontoret 293 riksbanksanstalter af olika slag. 
uppgingo vid slutet af år I898 till öfver 35 mill. mark - och den ofanligt stegrade rörelsen - den totala omsättningen öfverskred år 1898 den väldiga summan af 163 milliarder mark kunde ju motivera en höjning af den garantifond, som aktiekapitalet skulle utgöra.

Regeringen föreslog på dessa grunder en höjning af kapilet med 30 mill. mark, hvartill kom den ofvan nämnda förstärkningen af reservfonden på likaledes 30 mill. mark. Denna senare beräknades vara fullbordad under den kommande ıo-årsperioden, hvarefter bankens sammanlagda kapital alltså skulle utgöra 2 10 mill. mark. En jämförelse med de öfriga stora centralbankernas egna kapital visar följande resultat:

Englands bank . . . . . . . . . 358,6
Frankrikes bank . . . . . . I 82,3
Österrikisk-Ungerska banken . 208,3
Ryska Statsbanken . . . . . I I 4,5

Därvid är dock att märka, att dessa banker till stor del fastläst sina kapital $\mathrm{i}$ lån till sina respektive stater och därigenom - såsom regeringen $\mathrm{i}$ sin motivering anmärker - mer eller mindre dragit dessa från sin egentliga bestämmelse.

Opposionen framhöll, att det för att uppnå en lättnad på den inhemska penningmarknaden måste vara fördelaktigt, att tyskt kapital placerades $\mathrm{i}$ riksbanken $\mathrm{i}$ stället för $\mathrm{i}$ utländska.lån. Om detta nu också $\mathrm{i}$ viss mån måste erkännas som riktigt, så måste man likväl erinra sig hvilken liten roll en ytterligare ökning af bankens kapital på t. ex. 30 mill. i detta afseende skulle spela i betraktande af de högst betydande belopp, som den tyska marknaden under de senare åren alltjämt tecknat i utländska lån.

Gentemot tron på aktiekapitalets betydelse för ernåendet af en låg diskont kan för öfrigt med skäl anföras franska bankens exempel; denna bank håller som bekant $\mathrm{i}$ allmänhet en låg diskont trots sitt mycket ringa effektiva kapital.

Äfven frågan om kapitalförhöjningen måste afgöras genom en kompromiss: kapitalet skall år I 900 höjas med 30 mill. mark och före utgången af 1905 med ytterligare 30 mill. mark ${ }^{1}$. Re-

${ }^{1}$ Detta senare beslut måste väl betraktas som mycket oklokt: ingen kan säga hur penningmarknaden kan komma att ligga om 5 år; banken är nu emellertid under alla omständigheter tvungen att företa en kapitalförhöjning. 
servfonden skall som sagdt småningom ökas med 30 mill. mark, hvaraf en del genast vinnes genom agio vid aktieteckningen. Det sammanlagda kapitalet kommer således slutligen att bli 240 mill. mark.

\section{Den skattefria sedelkontingenten.}

Den tyska banklagen hade som bekant tilldelat hvar och en af de sedelutgifvande bankerna en viss sedelkontingent, d. v. s. rätt att utge obetäckta sedlar till ett visst belopp. Därutöfver kunde bankerna utge sedlar mot erläggande till riket af $5 \%$ ränta på det öfverskjutande beloppet. Riksbankens kontingent var nu 293,400,000 mark. Denna kontingent hade tidigare varit tillräcklig, men hade under de senaste åren allt oftare måst öfverskridas: I 895 i 3, I 896 i 6, I897 i 9, I 898 i I 6 veckoöfversikter.

Regeringen föreslog en höjning af riksbankens kontingent till 400 mill. mark. Oppositionen var äfven här angelägen att genom en ytterligare höjning af kontingenten göra en penningknapphet så sällsynt som möjligt. Under detta förslag låg uppenbarligen den föreställningen, att riksbankens diskontopolitik på något väsentligt sätt kunde influeras af den 5-procentiga beskattningen. Denna föreställning torde emellertid vara falsk: banken betalar nämligen skatt endast för den tid, som öfverskridandet af kontingenten varar, alltså $\mathrm{i}$ allmänhet för en mycket kort tid. Banken kan alltså, om den också endast ser på sin egen fördel, väl för t. ex. en vecka diskontera till $4 \%$ och betala en skatt af $5 \%$. Diskonterna kunna ju löpa en eller två månader efter sedan skatten upphört, och affären kan sålunda bli ganska vinstbringande, om man har att vänta ett snart återvändande af lätt penningställning med ty åtföljande låg diskont. Riksbanken har också upprepade gånger, trots det att kontingenten öfverskridits, fasthållit vid diskontsatser på 4 , ja t. o. m. $3 \%$.

A andra sidan visa erfarenheterna från slutet af $\mathrm{I} 898$, att riksbanken kan bli nödsakad att gå upp ända till $6 \%$ : det är då tydligt, att den s. k. indirekta kontingenteringen icke utgör orsaken till ränteförhöjningen.

Till fördel för hela det tyska kontingenteringssystemet torde knappast (hvad beträffar riksbanken, för privatbankerna har kon- 
tingenten en helt annan betydelse) något annat kunna anföras än, att kontingentens öfverskridande, ja redan ett försvagande af den skattefria reserven tjänar som en "varningstafla " för allmänheten. Vill man emellertid ha en sådan varningtafla, så synes det mig, att man kunde välja en, som stod i ett närmare orsaksförhållande till ränteförhöjningen än den obetäckta sedelstockens absoluta storlek. Gör man i det tyska systemet den skattefria kontingenten för stor, så löper man den faran, att allmänheten fortfar att betrakta en befintlig reserv som en garanti för penningställningen men nu kanske emellanåt med orätt. Från denna synpunkt sedt torde det måhända varit riktigare att, såsom under debatten föreslogs, för riksbanken alldeles afskaffa beskattningssystemet, än att - såsom man slutligen beslöt - höja den skattefria kontingenten till 450 mill. mark. En. dylik kontingent skulle riksbanken ingen enda gång före $\mathrm{I} 897$ ha uttömt.

\section{Guldförråd och guldpolitik.}

En af oppositionens viktigaste satser var, att den högre räntefot, som den kreditbehöfvande i Tyskland måste betala $\mathrm{i}$ jämförelse med sina konkurrenter $i$ de västliga grannländerna, $i$ främsta rummet berodde på. en guldknapphet i Tyskland. Särskildt påstod man, att de senaste årens räntestegring utes u tande var att hänföra till guldförluster, som Tyskland skulle ha lidit till följd af valutareformerna i Ryssland och Österrike-Ungern. Detta påstående sökte man ge en viss sannolikhet genom att hänvisa till de enorma guldförråd, som dessa båda länders centralbanker på de sista åren samlat, och som till en ej ringa del uppbragts genom lån på den tyska marknaden.

Man framförde som stöd för sina satser ett väldigt material af statistiska data, hvilka emellertid af regeringens ombud såväl $\mathrm{i}$ utskottsöfverläggningarne som $\mathrm{i}$ plenum underkastades en ingående kritik. Dessa debatter innehålla till följd häraf särdeles viktiga upplysningar öfver Tysklands monetära ställning, och en resumé af deras resultat torde därför vara af intresse.

Material för bedömande af Tysklands guldbalans lämnar 
först och främst den tyska handelsstatistiken ${ }^{1}$ som i denna fråga numera kan anses väsentligen korrekt. Den upptager följande guldposter:
I) "Bruchgold, Bruchsilber, Pagament»",
2) Myntadt guld,
3) Guld i stänger,
4) Guld och silfvervaror.

Den första af dessa poster har af statistici hittills i allmänhet försummats, antagligen af det skäl, att den officiella statistiken ej direkt anger guld- och silfvermängderna hvar för sig. Men då man känner såväl vikten som värdet af denna post, så låter sig ju den däri ingående guldmängden lätt beräknas ${ }^{3}$. Det visar sig, att denna guldmängd är af alldeles afgörande betydelse för det slutliga saldot. Posterna I), 2) och 3) gåfvo enligt regeringens uppgifter per saldo följande merimport:

$$
\begin{aligned}
& \text { I895 . . . } 28 \text { mill. mark } \\
& \text { I } 896 \ldots .34 \text { " \# } \\
& \text { I } 897 \ldots 45,6 \text { " . " } \\
& \text { I } 898 \ldots \text { I } \ldots \text { I } 7,7 \text { " " } \\
& \text { I } 880-\mathrm{I} 898 \ldots 869,5 \text { " . }
\end{aligned}
$$

Härtill kommer nu Tysklands guldproduktion, som under perioden $1880-1898$ uppgick till 97,3 mill. mark. ${ }^{4} \AA$ andra sidan måste man afdraga det guld, som förbrukas af industrien

1 "Monatliche Nachweise über den auswärtigen Handel»; årssammanfattningar i "Statistisches Jahrbuch für das Deutsche Reich".

${ }^{2}$ Pagament är i stänger sammansmält guld och silfver.

${ }^{3}$ Eri sådan beräkning har följande utseende: år 1897 importérades 36,7 ton pagament till ett värde af 12,3 mill. mark. Nu väga

$$
\text { I mill. nark silfver } 12,5 \text { ton, }
$$

alltså

$$
\text { I }) \text { guld } 0,36 \text { ” }
$$

och tillsammans 36,7 ton; hvaraf ekvationen

$$
\begin{aligned}
& x \text { " }) \text { silfver } 12,5 x \text { ” } \\
& y " \text { " guld } 0,36 y \text { ” }
\end{aligned}
$$

därjämte har man

$$
\text { I } 2,5 \cdot x+0,36 y=36,7 ;
$$

Häraf erhålles

$$
x+y=12,3 \text {. }
$$

$$
y=9,6 \text {, }
$$

d. v. s. den i posten I) ingående guldmängden var 9,6 mill. mark.

4 Denna produktion härrör till största delen från importerade malmer. 
och som uppskattas till c:a 30 mill. mark pr år ${ }^{1}$, alltså under den ifrågavarande perioden till 570 mill. mark. Posten n:o 4 här ofvan visar hufvudsakligen export, den behöfver naturligtvis ej särskildt räknas, då den totala industriella förbrukningen redan är afdragen.

Resultatet af denna beräkning är således, att Tyskland under perioden I 880 - I 898 för sina monetära behof vunnit guld för nära 400 mill. mark. Till jämförelse påvisade regeringens ombud, att Frankrike, hvars förhållanden oppositionen älskade att framställa som så ofantligt mycket gynsammare, under samma period förlorat guld för I 16,8 mill. mark. (Därvid måste emellertid tas $\mathrm{i}$ betraktande, att en sådan förlust vid sidan af Frankrikes absoluta guldförråd är att anse som ganska obetydlig.)

För bedömandet af utvecklingen sedan I895 lämna ofvanstående siffror viktiga upplysningar. Anslår man Tysklands guldproduktion under denna tid till 5 mill. mark pr år, den industriella förbrukningen till 30 mill. mark pr år, så har man att från hvarje års importsaldo afdraga c:a 25 mill. mark. Det visar sig därefter, att Tyskland under in tet enda af dessa år förlorat guld, icke ens i 895, då den bekanta häftiga tillbakagången i riksbankens metalliska kassa ägde rum. ${ }^{2}$ Regeringen var således i sin fulla rätt, då den påstod, att det guld som banken förlorat, hade gått till inre ändamål, tjänat de utomordentliga anspråk, som handel, industri och bergsbruk från och med I895 började ställa; och att det tyska banksystemet visat sig kunna försvara Tysklands guldförråd äfven gent emot de högst betydande kraf, som Ryssland, Österrike-Ungern och nyligen också Nord-Amerika ställt på den internationella guldmarknaden.

Att banken också låtit sig angeläget vara att $\mathrm{i}$ riklig mån ersätta den inre rörelsen de förluster, som uppstått genom export och insmältning af guldmynt, framgår af den officiella statistikens siffror: ${ }^{3}$ år I 895 präglades guldmynt för I I 4,8 mill. mark.

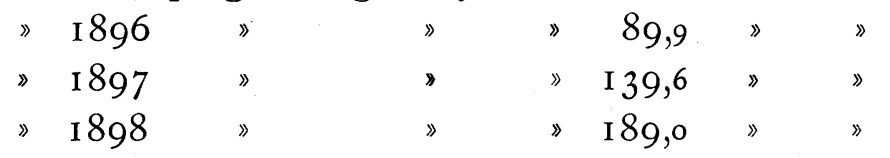

${ }^{1}$ Detta är nettoförbrukningen; dessutom förbrukas för ungef. I5 mill. mark gamla guldsaker; dessa siffror äro emellertid ganska osäkra; jfr Vierteljahrsheft zur Statistik des Deutschen Reiches I899, I.

${ }^{2}$ Den metalliska kassan förlorade från den is febr till den 3 Idec. 259 mill. mark.

${ }^{3}$ Statistischesyjahrbuch 1899 . 
alltså på 4 år en guldprägling af 533 mill. mark. Det framhölls också, gent emot oppositionens påståenden, att den tyska rörelsen faktiskt är mättad med guld - ett förhållande som torde kunna bestyrkas af hvar och en, som lefvat på olika platser i Tyskland. Det är naturligtvis omöjligt att lämna några exakta uppgifter om storleken af den i rörelsen befintliga penningmängden; men de på senare åren företagna kassaenquêterna lämna en inblick i cirkulationens procentuella sammansättning, som är af ett visst värde för bedömandet af ett lands monetära situation. Sålunda visade en mängd offentliga kassor hösten I 897 följande sammansättning:

\begin{tabular}{|c|c|c|}
\hline & i Tyskland & i Frankrike \\
\hline Guld & $35,3 \%$ & $\mathrm{I} 7,9 \%$ \\
\hline Sedlar & $53, \mathrm{I} \%$ & $7 \mathrm{I}, 7 \%$ \\
\hline Silfver & I I, $6 \%$ & $\mathrm{IO}, 4 \%$ \\
\hline
\end{tabular}

Så mycket om den faktiska ställningen.

Oppositionen framställde det förslaget, att banken, för att kunna försäkra sig själf ett större guldförråd och därigenom marknaden en billigare diskont, skulle:

I) i möjligast mån söka befordra guldinköp genom att förlänga de räntefria förskotten på guldimporter, särskildt från produktionsländerna, och genom en höjning af inköpspriset;

2) omedelbart låta utprägla allt inkommande guld, incl. främmande guldmynt;

3) motverka guldexport för arbitrageändamål genom att belägga för export lämpligt guld med en premie intill en procent

För att riktigt kunna klargöra innebörden af dessa förslag skall jag för ett ögonblick afvika från den hittills följda objektiva framställningen. Det gäller nämligen här i främsta rummet att strängt fastställa betydelsen af ordet "guldmyntfot» ( Goldwährung»). Härom råder icke sällan en viss oklarhet, som bland annat visar sig i det sätt, på hvilket teorien för de internationella betalningskurserna i allmänhet framställes. Det är icke strängt riktigt att säga, att $\mathrm{t}$. ex. Tysklands lagliga betalningsmedel är guld: det lagliga betalningsmedlet är riksmark, Tyskland har en "Reichsmarkwährung". En väsentlig betydelse för detta betalningsmedel ha emellertid vissa bestämmelser, som afse att instänga guldets pris i riksmark mellan tvänne bestämda gränser. Ju närmare dessa gränser ligga hvarandra, ju mer fulländad är landets 
guldmyntfot; men till ett absolut fastställande af guldets pris har man ännu ingenstädes kommit och skall förmodligen heller aldrig komma.

Guldprisets undre gräns fastställes i Tyskland genom den bestämmelsen, att riksbanken är skyldig att vid anfordan köpa guld till ett pris af I,392 mark pr halft kilogram. Den öfre gränsen är icke' så absolut bestämd: visserligen skall man teoretiskt taget för I,395 mark ha rätt att få $1 / 2$ kilogram guld; men då mynten icke kunna utpräglas med absolut noggrannhet (lagen medger ett fel af 2,5 pro mille $\mathrm{i}$ vikt, 2 pro mille $\mathrm{i}$ guldhalt), och då mynten i rörelsen nötas (nötningen får uppgå till 5 pro mille af vikten), så kan man anse, att en prisstegring af 7 pro mille är den yttersta tänkbara gränsen för en stegring af guldpriset (pr halfkilo) utöfver det normala priset af I,395 mark. Emellertid torde guldhalten i större mängder mynt lika ofta öfverskjuta som understiga den normala; och om man också utväljer lätta mynt, så torde det vara svårt att hopsamla en större mängd, som stå precis vid passervikten: man torde alltså kunna säga, att guldpriset ej kan stiga mer än 5 pro mille utöfver det normala, d. v. s. att den öfre gränsen skulle vara I,402 mark för halft kilo. Att Tyskland har en "Goldwährung", betyder således, att guldpriset lagligen är instängdt mellan gränserna I,392 och I,402 mark.

$\mathrm{Nu}$ är det klart, att ett korrekt uppehållande af guldmyntfoten egentligen förbjuder hvarje åtgärd, som syftar att föra guldpriset mot någon af gränserna, och framför allt, att hvarje försök att rubba dessa gränser är liktydigt med en förändring af landets valuta.

Från denna synpunkt måste oppositionens guldpolitik bedömas. Punkten I) i det ofvan citerade förslaget uttalar alldeles öppet en önskan, att banken skall höja inköpspriset för guld, hvilket är detsamma som att höja guldprisets undre gräns. Fordran att banken skall lämna räntefria förskott på i utlandet inköpt guld får väl mera anses som en omväg till en prisförhöjning: i den mån en sådan förskottspolitik kan anses lojal, har den nämligen sedan länge praktiserats af banken. Lika tydligt framträder i punkten 3) sträfvan att höja guldprisets offre gräns: den fordran, att banken skulle begära en guldpremie af ro pro mille är ju enligt det ofvan sagda liktydig med en höjning af guldprisets öfre 
gräns till I,409 mark. Denna fordran är nu först och främst orimlig, ty från den på guld rika tyska marknaden kan man alltid draga guld till betydligt billigare pris ${ }^{1}$. Men vore detta också icke fallet, så skulle banken, enligt hvad vi sett, icke kunna genomföra en sådan premiepolitik, utan att helt enkelt vägra att inlösa sina sedlar i guld. Detta kan tyska riksbanken verkligen göra, då de gamla thalerstyckena ännu äro lagligt betalningsmedel, (af dessa besitter banken vanligen närmare 200 mill. mark), men banken har hittills konsekvent följt den utan tvifvel korrekta politiken att icke begagna sig af denna rätt. Den af oppositionen föreslagna premiepolitiken betyder således $\mathrm{i}$ grunden ett öfvergifvande af guldmyntfoten och införandet af en dubbelmyntfot. Resolutionsförslaget har således en afgjordt bimetallistisk tendens, ehuru förslagsställarne på förhand lofvat att för denna gång lojalt ställa sig på guldmyntfotens grund.

Oppositionens hänvisning till den franska bankens premiepolitik kunde banklagens anhängare bemöta med uttalanden från framstående franska fackmän, särskildt franska bankens guvernör, som $\mathrm{i}$ sin berättelse för 1898 säger:

"nous dûmes recourir au seul remêde qu'en pareil cas conseille l'experience: l'élévation du taux de l'escompte".

Att den franska premiepolitiken icke hjälper mycket, visade sig hösten 1898 under penningknappheten i Tyskland, då franska banken från den $\mathrm{I}$ sept. till den $3 \mathrm{I}$ dec. på direkt och indirekt väg måste bidraga till guldexporten med c:a 67 mill. francs. - För öfrigt påpekades från regeringens sida, att gulduppköp i utlandet utan samtidig diskontförhöjning måste vara detsamma som att ösa vatten $\mathrm{i}$ ett såll.

Hvad slutligen punkten 2) i oppositionens program beträffar, så måste det naturligtvis anses som rent slöseri att låta omprägla mera utländskt mynt än som för den inre rörelsen är behöfligt. Har utlandet förfallna fordringar, som ej kunna gälldas med motsvarande förfallna fordringar på utlandet, och måste till följd däraf betalningar göras i guld, så blir det naturligtvis alltid billigare att göra denna betalning $\mathrm{i}$ utlandets mynt än $\mathrm{i}$ det af dessa mynt hopsmälta guldet; förfar man efter bimetallisternas recept, så blir följden helt enkelt den, att man måste ge ut mera guld än som

\footnotetext{
${ }^{1}$ Till en premie af högst 3,5 pro mille.
} 
annars vore nödvändigt. Något hinder för guldexport ligger naturligtvis ej i denna nedsmältningsmetod. Ty hvarken riksbanken eller någon annan bank lär väl sälja det utländska myntade guldet till lägre pris, än det skulle betinga efter en omprägling.

Oppositionens nu behandlade resolutionsförslag blef af riksdagen till alla delar förkastadt.

\section{Reglering af diskontsatserna.}

Det enda verkligt betydande, som regeringsförslaget innehöll utöfver den gamla banklagen, var ett förslag att binda de privata sedelutgifvande bankerna vid riksbankens diskontsatser. Detta förslag utgick därifrån, att de privata bankerna lätt kunde göra riksbankens diskontpolitik illusorisk, om det tillätes dem att fritt bestämma sin diskontsats. Riksbanken hade därför redan förut genom öfverenskommelser sökt försäkra sig om privatbankernas understöd för sin diskontpolitik, men denna utväg hade ej visat sig fullt pålitlig.

Saken komplicerades emellertid väsentligt därigenom, att de privata bankerna, så väl som efter deras föredöme riksbanken, infört bruket af en s. k. privatdiskont, d. v. s. de diskontera till lägre satser än de offentligen kungjorda. Denna lägre privatdiskont kommer naturligtvis endast vissa utvalda växlar till godo; så t. ex. plägar riksbanken fordra, att de växelförbundna tillsammans äga en riksbankskredit på minst 350,000 mark. Regeringens mening var, att de privata bankerna skulle ha rätt till privatdiskont till samma sats som riksbanken använde.

Diskussionen öfver detta kapitel kom därför att röra sig om två skilda punkter, I) frågan om en privatdiskont öfverhufvud borde tillåtas, 2) frågan om de enskilda bankernas ställning till riksbanken.

I den första punkten anförde oppositionen, att privatdiskonteringen var till fördel endast för en klass af rika bankirer och börsmän, och därför rätt och slätt borde förbjudas. Regeringen invände, att äfven smärre affärsmän kunde komma i åtnjutande af den lägre diskontsatsen genom förbindelse med en bankir. Det torde dock vara tvifvelaktigt, om icke bankiren vid en sådan transaktion behåller förtjänsten för sig. 
Vidare framhöll oppositionen, att ett förbud mot privatdiskont vid riklig penningtillgång skulle tvinga riksbanken till en hastigare och betydligare sänkning af sin officiella diskontsats; hvarpå regeringen svarade, att en officiell sats af 2 eller $2^{1 / 2} \%$ kunde locka till öfverspekulation och därigenom blifva farlig.

Efter en kompromiss enade man sig slutligen om den bestämmelsen, att riksbanken icke får diskontera under sin enligt banklagen offentliggjorda sats, så snart denna uppnår eller öfverskrider $4 \%$; i de fall då privatdiskont förekommer, skall diskontosatsen offentliggöras.

I själfva hufvudfrågan, huruvida privatbankernas diskontsatser borde vara bundna vid riksbankens, kom det till långvariga strider. Här hade regeringen att kämpa med representanter för de sydtyska staterna, hvilka lägga stor vikt vid uppehållandet af sina sedelutgifvande banker, och som $\mathrm{i}$ regeringens fordringar sågo en högst betydlig inskränkning $\mathrm{i}$ dessa bankers privilegier ${ }^{1}$. För öfrigt såg naturligtvis den öfriga oppositionen i privatbankernas konkurrens ett godt medel att nedbringa den allmänna räntefoten.

Resultatet blef en kompromiss, som förbjuder privatbankerna att diskontera under riksbankens diskontsats, så snart denna uppnått eller öfverstigit $4 \%$, men som $\mathrm{i}$ andra fall tillåter privatbankerna att diskontera intill $1 / 4$ procent under riksbankens officiella sats och intill $1 / 8$ procent under riksbankens privatsats.

$$
\text { * * * }
$$

Som man ser har det således lyckats att få den tyska banklagen förnyad, utan att behöfva uppoffra några af de grundprinciper, hvarpå denna lag är byggd. Riksbanken är fortfarande försäkrad den förträffliga ledning, den hittills haft, och hvars styrka ligger $\mathrm{i}$ dess fullständiga oberoende af alla för en god bankpolitik främmande inflytanden, de må nu bestå i påtryckningar från statsmakterna eller enskilda affärskretsar eller $\mathrm{i}$ ett

${ }^{1}$ De fortfarande bestående privatbankerna äro:

Frankfurter Bank med rätt till obetäckt sedelutgifning af ıo mill. mark

Bayerische Notenbank

mill. mar
»)

Sächsische Bank zu Dresden

$\begin{array}{lll}32 & \text { ) } \\ \text { I6,77I })\end{array}$

Würtembergische Notenbank ............................. I0 》 》

Badische Bank ................................................ 10 ग 》

Bank für Süddeutschland ................................. 10 ग 》

Ekonomisk Tidskrift. 1899. 
olämpligt och ensidigt fullföljande af bankens vinstintresse. Riksbankens ställning har blifvit stärkt, om icke så mycket i ekonomiskt afseende, så dock $\mathrm{i}$ politiskt: oppositionens sträfvanden äro väl $\mathrm{i}$ detta ögonblick mera utsiktslösa än någonsin. Och om man också icke lyckades förlänga lagen på mer än Io år (från vissa håll hade en förlängning på 20 à 30 år planerats), så torde likväl det tyska banksystemet nu ha utträdt ur försöksstadiet och för framtiden komma att bilda ett fast stöd för Tysklands penningväsen och näringslif.

Göttingen i juli I 899 . 